\title{
Pengujian Daya Hasil Beberapa Varietas Tanaman Jagung pada Kondisi Cekaman Kekeringan yang Diberi Pupuk Kandang di Lahan Kering Lombok Utara
}

\author{
Evaluation of Some Varieties of Maize with Drought Condition under \\ Different Rates of Manure on Dry Land of Northern Lombok
}

\author{
IGM Kusnarta*1) dan IW.Sudika ${ }^{2)}$ \\ ${ }^{1)}$ Jurusan Ilmu Tanah dan ${ }^{2)}$ Jurusan Budidaya Pertanian \\ Fakultas Pertanian, Universitas Mataram, Indonesia \\ Jln Majapahit No. 62 Mataram NTB-INDONESIA \\ *Email: igm_kusnarta@yahoo.com
}

Manuscript received: 23-04-2018. Accepted:02-06-2018

\begin{abstract}
ABSTRAK
Penelitian ini bertujuan untuk mengetahui daya hasil beberapa varietas tanaman jagung yang diberi berbagai takaran pupuk kandang pada kondisi cekaman kekeringan di lahan kering Lombok Utara. Percobaan dirancang menggunakan Rancangan Petak Terbagi, dengan takaran pupuk kandang (0, 5, 10, 15, dan 20 t.ha $^{-1}$ ) sebagai petak utama, dan lima macam varietas (P4IS, Gumarang, Lamuru, Sukmaraga dan Hibrida NK212) sebagai anak petak.Daya hasil diukur dari bobot biji kering pipil per tanaman. Data hasil percobaan dianalisa menggunakan analisis sidik ragam pada taraf nyata 5 persen. dan uji Beda Nyata Jujur (BNJ) pada taraf nyata sama. Hasil penelitian menunjukkan bahwa daya hasil tanaman jagung tertinggi diperoleh pada varietas Lamuru pada takaran pupuk kandang sapi 20 t.ha ${ }^{-1}$, yakni 85.94 gram per tanaman $\left(6.14 \mathrm{t}_{\mathrm{h}} \mathrm{ha}^{-1}\right)$. Daya hasil varietas Lamuru sama dengan Sukmaraga dan lebih tinggi dibandingkan dengan P4IS, Gumarang dan Hibrida NK212. Takaran pupuk kandang sebesar 20 t.ha ${ }^{-1}$ memberikan daya hasil tanaman jagung tertinggi.
\end{abstract}

Kata kunci: biji pipilan, Lamuru, Gumarang, Sukmaraga, hibrida

\begin{abstract}
This study aimed to determine the efficacy of several varieties of maize at various rate of manure under drought condition on the dry land of North Lombok. The experiments were designed using split plot design, with manure rates $\left(0,5,10,15\right.$ and 20 t.ha $\left.^{-1}\right)$ as the main plots, and five different maize varieties (P4IS, Gumarang, Lamuru, Sukmaraga and NK212 Hybrid) as subplots. The efficacy of several maize varieties were determined from the weight of dry seeds per plant. Experimental data were analyzed using analysis of variance (ANOVA) at 5 percent significant levels. The mean of each treatments was further tested using the Honestly Significant Difference (HSD) at the same level. The results showed that the highest yield of maize crop was obtained on Lamuru variety at rate of manure of $20 \mathrm{t} / \mathrm{ha}$, ie $85.94 \mathrm{~g}$.plant ${ }^{-1}$ or $6.14 \mathrm{t}^{\mathrm{h}} \mathrm{ha}^{-1}$. The yield of Lamuru variety is similar to that of Sukmaraga, but it is higher compared to P4IS, Gumarang and Hybrid of NK212. The highest yield of maize crop was obtained at rate of manureof $20 \mathrm{t} \cdot \mathrm{ha}^{-1}$.
\end{abstract}

Keywords: seed, Lamuru, Gumarang, Sukmaraga, hybrid. 


\section{PENDAHULUAN}

Penanaman jagung di Indonesia sekitar 60 persen dilakukan di lahan kering ((Indriani dan Mejaya, 2012); salah satunya di Nusa Tenggara Barat (NTB).Oleh karenanya, diperlukan varietas yang sesuai untuk lahan kering. Menurut Mejaya et al.(2010), bahwa varietas unggul yang lebih sesuai untuk lahan kering adalah varietas bersari bebas (komposit/sintetik).

Sudika et al. (2014), telah memperoleh populasi komposit, yakni P4IS melalui seleksi indeks selama 4 siklus di lahan kering.Daya hasil populasi ini cukup tinggi yakni sekitar 5.5 t.ha ${ }^{-1}$ dan umur panen tergolong super genjah (78-79 hari)serta bersifat stay-green. Hasil penelitian Jaya et al. (2015) di lahan kering pada musim hujan dengan air yang cukup, diperoleh daya hasil beberapa varietas hibrida, yaitu Bisi-816 sebesar 6.26 t.ha $^{-1}$; Pioneer-21, 6.84 t.ha $^{-1}$; Pertiwi-2, 5.78 t.ha $^{-1}$ dan NK-212 sebesar 6.98 t.ha $^{-1}$. Indriani dan Mejaya (2012) memperoleh, bahwa daya hasil varietas Lamuru sebesar 2.81 t.ha $^{-1}$ di lahan kering pada kondisi cukup air (normal). Hasil penelitian Tajidan (2014), menunjukkan bahwa rata-rata hasil pipilan kering jagung hibrida di lahan kering pada tingkat petani masih rendah, yakni sekitar 3.7 t.ha $^{-1}$ dan sering mengalami kegagalan akibat varietas yang ditanam tidak tahan terhadap kekeringan.

Secara umum, ideotipe tanaman jagung yang toleran cekaman kekeringan antara lain biomass sebelum keluar bunga betina tinggi, bersifatstay-green dan daun lebih tebal dan berlilin (Anonymous, 2012). Karakter-karakter yang berkaitan dengan kekeringan meliputi perkecambahan, pertumbuhan, fotosintesis, perkembangan organ reproduksi dan pembentukan biji, komponen hasil dan hasil. (Hasanuzzaman et al., 2014). Menurut Xoconostle-Cazeres et al. (2012), karakter yang berkaitan dengan kekeringan yaitu tinggi tanaman, pembungaan dan hasil. Edmeades (2013), menggambarkannya dari indeks panen.Kemampuan tanaman untuk mempertahankan daun tetap hijau (sifat stay green) saat terjadi kekeringan, mempengaruhi kemampuan pengisian biji dan akhirnya berpengaruh terhadap hasil. Selisih keluar rambut tongkol dan keluar malai (ASI) juga menentukan daya hasil pada cekaman kekeringan (Efendi dan Azrai, 2010).

Lahan kering umumnya memiliki kandungan bahan organik rendah akibat cepatnya terdegradasi. Penambahan bahan organik di lahan kering umumnya sangat nyata meningkatkan pertumbuhan dan produksi tanaman jagung. Pemberian bahan organik dalam tanah dapat meningkatkan kemampuan tanah untuk mengikat air, memperbaiki struktur tanah dan memperbaiki sifat kimia tanah seperti peningkatan kapasitas tukar kation (KPK), kandungan unsur hara (Atmojo, 2003). Dosis pupuk kandang sapi berpengaruh terhadap produksi. Produksi rata-rata jagung pada lahan kering di Lahan Percobaan IPB Jonggol masih rendah apabila dibandingkan dengan potensi hasil jagung hibrida (13.3 t.ha $\left.{ }^{-1}\right)$. Dosis pupuk 10 t.ha $^{-1}$ dan 15 t.ha $^{-1}$ lebih baik dibanding tanpa dipupuk dan dipupuk dengan dosis 5 t.ha ${ }^{-1}$ (Bara dan Chozin, 2010). Hasil penelitian Adijaya dan Yasa (2014), menunjukkan bahwa pupuk kandang sapi dapat memperbaiki sifat fisik tanah. Peningkatan dosis pupuk kandang sampai pada dosis 15 t.ha $^{-1}$ menurunkan bulk density saat panen, meningkatkan kadar air tanah dan meningkatkan ruang pori. Penelitian yang telah dilakukan bertujuan untuk mengetahui daya hasil beberapa varietas komposit dan satu varietas hibrida yang diberi pupuk kandang sapi pada kondisi cekaman kekeringan di lahan kering. 


\section{BAHAN DAN METODE}

\section{Rancangan percobaan}

Metode ekperimental digunakan dalam percobaan ini dan perlakuan dirancang dengan rancangan petak terbagi (split plot design). Varietas tanaman jagung ditempatkan sebagai anak petak sebanyak 5 macam, yaitu V1 (P4IS), V2 (Gumarang), V3 (Lamuru), V4 (Sukmaraga) dan V5 (NK212). Takaran pupuk kandang sapi terdiri atas 5 taraf, yaitu D0 (tanpa pupuk kandang), D1 (pupuk kandang 5 t.ha ${ }^{-1}$ ), D2 (pupuk kandang 10 t.ha ${ }^{-1}$ ), D3 (pupuk kandang 15 t.ha ${ }^{-1}$ ) dan D4 (pupuk kandang 20 t.ha ${ }^{-1}$ ).

\section{Pelaksanaan percobaan}

Percobaan dilakukan mulai awal bulan April sampai dengan bulan awal bulan Agustus 2017. Tanah yang digunakan memiliki tekstur pasiran.Lahan percobaan diolah dengan membajak dan menggaru sebanyak satu kali, kemudian petakan dibagi 3 blok dengan jarak antar blok $1 \mathrm{~m}$. Dalam setiap blok dibagi 5 sub blok masing-masing sebagai petak utama dan dalam setiap sub blok dibagi menjadi 5 plot yang merupakan anak petak. Pupuk kandang diberikan sehari sebelum tanam dengan cara menyebarkan secara merata dalam bedengan, kemudian dicampurkan dengan tanah menggunakan cangkul.

Penanaman dilakukan secara tugal dua biji per lubang dengan jarak tanam $20 \times 70 \mathrm{~cm}$ kemudian lubang ditutup dengan tanah dan umur 10 hari diperjarang hingga satu tanaman per lubang. Setiap perlakuan ditanam dua baris sepanjang $5 \mathrm{~m}$, sehingga jumlah populasi maksimal 50 tanaman. Sebelum tanam, benih terlebih dahulu diperlakukan dengan Saromyl 35 SD dengan dosis $2 \mathrm{~g}$ untuk setiap $1 \mathrm{~kg}$ benih untuk mencegah penyakit bulai. Pada lubang tanam tersebut diberikan pula Furadan $3 \mathrm{G}$ dengan dosis $20 \mathrm{~kg} \cdot \mathrm{ha}^{-1}$. Pemberian pupuk Urea menggunakan dosis $200 \mathrm{~kg} \cdot \mathrm{ha}^{-1}$ yang diberikan dua kali, yaitu pada saat tanam bersamaan dengan pemberian Ponska, sebanyak $100 \mathrm{~kg} \cdot \mathrm{ha}^{-1}$ dan umur 21 hari setelah tanam sebagai pupuk susulan sebanyak 100 kg.ha ${ }^{-1}$. Dosis pupuk Ponska adalah 300 kg.ha ${ }^{-1}$. Pupuk Urea dan Ponska diberikan dengan cara tugal di kiri-kanan lubang tanam dengan jarak sekitar 5-7.5 cm dari lubang tanam.

Pemeliharaan tanaman lainnya meliputi pengairan, penyiangan dan pembumbunan serta pengendalian hama/penyakit. Pengairan tidak dilakukan, sepenuhnya tergantung dari curah hujan. Penyiangan dan pembumbunan dilakukan satu kali yaitu pada umur 21 harisetelah tanam. Pengendalian hama menggunakan Furadan $3 \mathrm{G}$ yang diberikan pada lubang tanam pada saat tanam. Panen dilakukan apabila tanaman telah menunjukkan kriteria panen, yaitu kelobot dan rambut tongkol telah kering dan biji telah keras; yang apabila dipijit tidak berbekas.

\section{Observasi dan analisi data}

Sifat yang diamati meliputi tinggi tanaman, jumlah daun per tanaman, saat keluar malai, saat keluar rambut tongkol, umur panen, panjang tongkol, diameter tongkol, bobot tongkol kering panen per tanaman, bobot biji kering pipil per tanaman dan bobot 1.000 butir biji. Data hasil percobaan dianalisa dengan analisis sidik ragam mengikuti rancangan petak terbagi. Apabila antar perlakuan berbeda nyata, maka dilakukan uji lanjut dengan uji beda nyata jujur (BNJ) pada taraf nyata 5 persen. 


\section{HASIL DAN PEMBAHASAN}

Pengaruh Macam Varietas dan Takaran Pupuk Kandang Sapi terhadap Daya Hasil Tanaman Jagung

Dalam penelitian ini terdapat interaksi nyata antara macam varietas dan dosis pupuk kandang sapi. Interaksi tersebut nyata khususnya pada daya hasil, dengan rata-rata setiap perlakuan disajikan pada Tabel 1. Pada Tabel 1 tampak, bahwa daya hasil (bobot biji kering pipil per tanaman) tertinggi diperoleh pada D4V3 (varietas Lamuru, takaran 20 t.ha $^{-1}$ ), yakni 85.94 gram.

Tabel 1. Rata-rata daya hasil lima varietas dan takaran pupuk kandang Sapi

\begin{tabular}{|c|c|c|c|c|c|}
\hline \multirow{2}{*}{$\begin{array}{l}\text { Macam } \\
\text { varietas }\end{array}$} & \multicolumn{5}{|c|}{ Takaran pupuk kandang sapi $\left(\mathrm{t} . \mathrm{ha}^{-1}\right)^{*}$} \\
\hline & 0 & 5 & 10 & 15 & 20 \\
\hline P4IS & $41.15 \mathrm{kl}$ & $46.96 \mathrm{ijk}$ & 50.81 hgij & 54.27 efghi & $58.31 \mathrm{efgh}$ \\
\hline Gumarang & $41.99 \mathrm{jkl}$ & $34.79 \mathrm{i}$ & $47.47 \mathrm{ik}$ & $60.29 \mathrm{def}$ & 52.19 fghi \\
\hline Lamuru & $50.45 \mathrm{hij}$ & 59.61 defg & $68.30 \mathrm{bcd}$ & $58.33 \mathrm{efgh}$ & $85.94 \mathrm{a}$ \\
\hline Sukmaraga & $49.00 \mathrm{ijk}$ & 62.65 cde & $71.40 \mathrm{bc}$ & $73.46 \mathrm{~b}$ & $72.40 \mathrm{~b}$ \\
\hline NK212 & $46.41 \mathrm{ijk}$ & $58.44 \mathrm{efgh}$ & 55.37 efghi & $68.15 \mathrm{bcd}$ & $72.75 \mathrm{~b}$ \\
\hline
\end{tabular}

Keterangan: *) Angka-angka pada kolom dan baris yang diikuti huruf sama berbeda tidak nyata menurut uji BNJ 5 persen

Pengaruh Macam Varietas Tanaman Jagung terhadap Pertumbuhan dan Daya Hasil Tanaman Jagung

Rata-rata tinggi tanaman dan jumlah daun per tanaman setiap varietas tanaman jagung yang diuji, disajikan pada Tabel 2; sedangkan rata-rata umur keluar malai, umur keluar rambut tongkol dan selisihnya (ASI) serta umur panen, disajikan pada Tabel 3. Nilai rata-rata untuk komponen hasil dan hasil disajikan pada Tabel 4.

Tabel 2. Rata-rara tinggi tanaman $(\mathrm{cm})$ dan jumlah daun pertanaman (helai) setiap varietas

\begin{tabular}{lcccccc}
\hline \multicolumn{1}{c}{$\begin{array}{c}\text { Perlakuan } \\
\text { (Varietas) }\end{array}$} & 1 & 2 & 3 & 4 & 5 & 6 \\
\cline { 2 - 7 } & $23.05 \mathrm{a}$ & 48.01 & $114.45 \mathrm{a}$ & 4.83 & 7.40 & $12.51 \mathrm{a}$ \\
P4IS & $26.84 \mathrm{~b}$ & 49.23 & $92.81 \mathrm{~b}$ & 4.76 & 7.47 & $11.36 \mathrm{~b}$ \\
Gumarang & $29.06 \mathrm{c}$ & 47.24 & $86.60 \mathrm{~b}$ & 4.80 & 7.59 & $10.48 \mathrm{c}$ \\
Lamuru & $32.32 \mathrm{~d}$ & 52.38 & $96.19 \mathrm{~b}$ & 4.96 & 7.67 & $10.84 \mathrm{~b}$ \\
Sukmaraga & $27.54 \mathrm{~b}$ & 50.20 & $91.23 \mathrm{~b}$ & 5.15 & 7.61 & $10.51 \mathrm{c}$ \\
HibridaNK212 & 1.31 & \multicolumn{7}{c}{11.32} \\
\hline \multicolumn{1}{c}{ BNJ $_{0.05}$} & & & & & 0.75 \\
\hline
\end{tabular}

Keterangan: *) Angka-angka pada kolom sama diikuti oleh huruf sama tidak berbeda nyata menurut uji $\mathrm{BNJ}_{0.05} ; 1$, tinggi tanaman umur 14 hari $(\mathrm{cm}) ; 2$, tinggi tanaman umur 28 hari $(\mathrm{cm}) ; 3$, tinggi tanaman umur 42 hari $(\mathrm{cm}) ; 4$, jumlah daun umur 14 hari (helai); 5, jumlah daun umur 28 hari (helai) dan 6, jumlah daun umur 42 hari (helai).

Pada Tabel 2 terlihat, bahwa tinggi tanaman umur 14 hari antar kelima varietas tanaman jagung yang diuji berbeda. Tanaman tertinggi diperoleh pada varietas komposit Sukmaraga dan terendah pada populasi P4IS. Pada umur 42 hari, tanaman tertinggi diperoleh 
pada populasi P4IS dan keempat varietas unggul sama. Jumlah daun tanaman jagung pada saat umur 14 hari dan 28 hari kelima varietas yang diuji berbeda tidak nyata; sedangkan pada saat umur 42 hari, jumlah daun terbanyak diperoleh pada populasi P4IS; sedangkan jumlah daun yang paling sedikit pada varietas Lamuru dan NK212.

Pada Tabel 3 terlihat, bahwa saat keluarnya malai dan umur keluar rambut tongkol paling cepat diperoleh pada populasi P4IS, kemudian diikuti oleh Gumarang dan paling lambat pada hibrida NK212. Nilai ASI (anthesis silking interval) berbeda tidak nyata diantara kelima varietas yang diuji yaitu berkisar 3.33-4.00 hari. Terkait dengan umur panen, maka varietas yang paling genjah diperoleh pada populasi P4IS dan diikuti oleh Gumarang, Lamuru, Sukmaraga, sedangkan paling dalam pada NK212.

Tabel 3. Rata-rata umur keluar malai, umur keluar rambut tongkol, ASI dan umur panen setiap varietas

\begin{tabular}{lcccc}
\hline \multirow{2}{*}{$\begin{array}{c}\text { Perlakuan } \\
\text { (Varietas) }\end{array}$} & \multicolumn{4}{c}{ Karakter yang diamati *) } \\
\cline { 2 - 5 } & 1 & 2 & 3 & 4 \\
\hline P4IS & $42.27 \mathrm{a}$ & $45.80 \mathrm{a}$ & 3.53 & $76.80 \mathrm{a}$ \\
Gumarang & $48.67 \mathrm{~b}$ & $52.07 \mathrm{~b}$ & 3.40 & $79.60 \mathrm{~b}$ \\
Lamuru & $51.73 \mathrm{~cd}$ & $55.73 \mathrm{c}$ & 4.00 & $85.80 \mathrm{c}$ \\
Sukmaraga & $51.07 \mathrm{c}$ & $54.53 \mathrm{~d}$ & 3.47 & $89.60 \mathrm{~d}$ \\
Hibrida NK212 & $52.20 \mathrm{~d}$ & $55.53 \mathrm{c}$ & 3.33 & $95.13 \mathrm{e}$ \\
\hline \multicolumn{1}{c}{ BNJ $_{0.05}$} & 0.70 & 0.63 & 0.35 \\
\hline
\end{tabular}

Keterangan: *) Angka-angka pada kolom sama diikuti oleh huruf sama tidak berbeda nyata menurut uji $\mathrm{BNJ}_{0.05} ; 1$, umur keluar malai (hari); 2, umur keluar rambut tongkol (hari); 3,ASI (hari) dan 4, umur panen (hari).

Tabel 4. Rata-rata komponen hasil dan hasil setiap varietas tanaman jagung

\begin{tabular}{|c|c|c|c|c|c|c|}
\hline \multirow{3}{*}{$\begin{array}{l}\text { Perlakuan } \\
\text { (Varietas) }\end{array}$} & \multicolumn{6}{|c|}{ Karakter yang diamati $*$ ) } \\
\hline & \multirow[t]{2}{*}{1} & \multirow[t]{2}{*}{2} & \multirow[t]{2}{*}{3} & \multirow[t]{2}{*}{4} & \multicolumn{2}{|c|}{5} \\
\hline & & & & & g. $\tan ^{-1}$ & t.ha $^{-1}$ \\
\hline P4IS & $106.03 \mathrm{a}$ & $11.45 \mathrm{a}$ & $4.17 \mathrm{a}$ & $50.30 \mathrm{a}$ & $199.35 \mathrm{a}$ & 3.593 \\
\hline Gumarang & $103.11 \mathrm{a}$ & $11.73 \mathrm{a}$ & $4.16 \mathrm{a}$ & $47.35 \mathrm{a}$ & $174.60 \mathrm{~b}$ & 3.382 \\
\hline Lamuru & $123.15 \mathrm{~b}$ & $12.44 \mathrm{~b}$ & $4.33 \mathrm{~b}$ & $64.53 \mathrm{~b}$ & $230.01 \mathrm{c}$ & 4.609 \\
\hline Sukmaraga & $133.98 \mathrm{c}$ & $12.79 \mathrm{~b}$ & $4.39 \mathrm{~b}$ & $65.78 \mathrm{~b}$ & $236.50 \mathrm{c}$ & 4.699 \\
\hline Hibrida NK212 & $114.50 \mathrm{~d}$ & $12.59 \mathrm{~b}$ & $4.28 \mathrm{~b}$ & $60.22 \mathrm{c}$ & $250.35 \mathrm{~d}$ & 4.302 \\
\hline $\mathrm{BNJ}_{0.05}$ & 6.69 & 0.53 & 0.06 & 3.10 & 7.46 & \\
\hline
\end{tabular}

Keterangan: *) Angka-angka pada kolom sama diikuti oleh sama tidak berbeda nyata menurut uji

$\mathrm{BNJ}_{0.05} ; 1$, bobot tongkol kering panen per tanaman $(\mathrm{g}) ; 2$, panjang tongkol $(\mathrm{cm}) ; 3$, diameter tongkol $(\mathrm{cm})$; 4, bobot biji kering pipil per tanaman (g) dan5, bobot 1.000 butir biji (g).

Pada Tabel 4 ditunjukkan, bahwa varietas Lamuru memiliki bobot tongkol kering panen per tanaman tertinggi; sedangkan untuk panjang tongkol dan diameter tongkol varietas Lamuru, Sukmaraga dan NK212 lebih tinggi dibandingkan dengan populasi P4IS dan Gumarang. Daya hasil (bobot biji kering pipil per tanaman), bobot 1.000 butir biji tertinggi diperoleh pada varietas Lamuru dan Sukmaraga. Daya hasil varietas Lamuru dan Sukmaraga berturut-turut 230.01 g.tan ${ }^{-1}$ (setara dengan 4.609 t.ha $^{-1}$ ) dan 236.50 g.tan ${ }^{-1}$ (setara dengan 4.699 t.ha $\left.{ }^{-1}\right)$. 


\section{Pengaruh Takaran Pupuk Kandang Sapi terhadap Pertumbuhan dan Daya Hasil Tanaman Jagung}

Rata-rata tinggi tanaman dan jumlah daun untuk setiap takaran pupuk kandang sapi, disajikan pada Tabel 5 dan pada Tabel 6, disajikan rata-rata umur keluar malai, umur keluar rambut tongkol, ASI dan umur panen. Rata-rata untuk setiap komponen hasil dan hasil disajikan pada Tabel 7. Pada Tabel 5 dapat dilihat, bahwa rata- rata tinggi tanaman dan jumlah daun per tanaman umur 14, 28 dan 42 hari sama antar kelima takaran pupuk kandang sapi; sedangkan rata-rata jumlah daun per tanaman umur 42 hari, dosis 20 t.ha $^{-1}$ tertinggi, yakni 12.16 helai.

Tabel 5. Rata-rata tinggi tanaman umur, jumlah daun untuk setiap takaran pupuk kandang sapi

\begin{tabular}{ccccccc}
\hline $\begin{array}{c}\text { Takaran pupuk } \\
\text { kandang sapi }\end{array}$ & 1 & 2 & 3 & 4 & 5 & 6 \\
\hline 0 t.ha $^{-1}$ & 28.63 & 47.94 & 99.15 & 4.71 & 6.84 & $10.32 \mathrm{a}$ \\
5 t.ha $^{-1}$ & 29.96 & 47.91 & 85.67 & 4.79 & 7.24 & $10.76 \mathrm{a}$ \\
10 t.ha $^{-1}$ & 28.71 & 48.33 & 84.22 & 4.81 & 7.64 & $10.87 \mathrm{ab}$ \\
15 t.ha $^{-1}$ & 28.90 & 48.91 & 101.62 & 5.07 & 7.92 & $11.59 \mathrm{~b}$ \\
20 t.ha $^{-1}$ & 22.62 & 53.97 & 110.63 & 5.12 & 8.09 & $12.16 \mathrm{c}$ \\
\hline BNJ $_{0.05}$ & & \multicolumn{7}{c}{} & $\mathbf{0 . 7 5}$ \\
\hline
\end{tabular}

Keterangan: *) Angka-angka pada kolom sama diikuti oleh huruf sama tidak berbeda nyata menurut uji $\mathrm{BNJ}_{0.05} ; 1$, tinggi tanaman umur 14 hari $(\mathrm{cm}) ; 2$, tinggi tanaman umur 28 hari $(\mathrm{cm}) ; 3$, tinggi tanaman umur 42 hari (cm); 4, jumlah daun umur 14 hari (helai); 5, jumlah daun umur 28 hari (helai) dan 6, jumlah daun umur 42 hari (helai).

Tabel 6. Rata-rata umur keluar malai, umur keluar rambut tongkol, ASI, dan umur panen untuk setiap takaran pupuk kandang sapi

\begin{tabular}{ccccc}
\hline Takaran pupuk & \multicolumn{4}{c}{ Karakter yang diamati *) } \\
\cline { 2 - 5 } kandang sapi & 1 & 2 & 3 & 4 \\
\hline 0 t.ha $^{-1}$ & 49.47 & 53.20 & 3.73 & $85.40 \mathrm{a}$ \\
5 t.ha $^{-1}$ & 48.47 & 52.47 & 4.00 & $85.33 \mathrm{ab}$ \\
10 t.ha $^{-1}$ & 49.20 & 52.40 & 3.20 & $85.00 \mathrm{~b}$ \\
15 t.ha $^{-1}$ & 49.00 & 52.60 & 3.60 & $85.27 \mathrm{ab}$ \\
20 t.ha $^{-1}$ & 49.80 & 53.00 & 3.20 & $85.93 \mathrm{c}$ \\
\hline BNJ $_{0.05}$ & & & $\mathbf{0 . 3 5}$ \\
\hline
\end{tabular}

Keterangan: *) Angka-angka pada kolom sama diikuti oleh huruf sama tidak berbeda nyata menurut uji $\mathrm{BNJ}_{0.05} ; 1$, umur keluar malai (hari); 2, umur keluar rambut tongkol (hari); 3,ASI (hari) dan 4, umur panen (hari).

Takaran pupuk kandang sapi tidak menyebabkan perbedaan terhadap umur keluar malai, umur keluar rambut tongkol dan selisih keluar rambut tongkol dan keluar malai (ASI). Takaran pupuk kandang sapi menyebabkan perbedaan umur panen, yakni yakni paling dalam pada takaran 20 t.ha ${ }^{-1}$. Takaran pupuk kandang 5, 10 dan 15 t.ha $^{-1}$ menyebabkan umur panen sama.

Pada Tabel 7 terlihat, bahwa takaran pupuk kandang sapi 20 t.ha ${ }^{-1}$, menyebabkan bobot tongkol kering panen per tanaman lebih tinggi, tongkol lebih panjang dan diameter tongkol lebih besar dibandingkan takaran yang lebih rendah. Demikian pula untuk bobot biji 
kering pipil per tanaman (daya hasil) tertinggi diperoleh pada takaran 20 t.ha ${ }^{-1}$; sedangkan bobot 1.000 butir biji, takaran 15 dan 20 t.ha $^{-1}$ lebih tinggi dibandingkan takaran 0,5 dan 10 t.ha ${ }^{-1}$.

Tabel 7. Rata-rata bobot tongkol kering panen, panjang tongkol, diameter tongkol, bobot biji kering pipil per tanaman, bobot 1.000 butir biji dan daya hasil (bobot biji kering pipil per plot) untuk setiap takaran pupuk kandang sapi

\begin{tabular}{|c|c|c|c|c|c|c|}
\hline \multirow{2}{*}{$\begin{array}{l}\text { Takaran pupuk } \\
\text { kandang sapi }\end{array}$} & \multicolumn{5}{|c|}{ Karakter yang diamati $*$ ) } & \multirow{2}{*}{$\begin{array}{c}\text { Daya hasil } \\
\left(\mathrm{t}^{\prime} \mathrm{ha}^{-1}\right)\end{array}$} \\
\hline & 1 & 2 & 3 & 4 & 5 & \\
\hline 0 t.ha $^{-1}$ & $94.88 \mathrm{a}$ & $10.97 \mathrm{a}$ & $4.09 \mathrm{a}$ & $45.80 \mathrm{a}$ & $202.53 \mathrm{a}$ & 3.272 \\
\hline 5 t.ha ${ }^{-1}$ & $103.37 \mathrm{~b}$ & $11.29 \mathrm{a}$ & $4.16 \mathrm{~b}$ & $52.49 \mathrm{~b}$ & $210.70 \mathrm{~b}$ & 3.749 \\
\hline 10 t.ha $^{-1}$ & $122.19 \mathrm{c}$ & $11.88 \mathrm{~b}$ & $4.18 \mathrm{~b}$ & $58.67 \mathrm{c}$ & $217.07 \mathrm{~b}$ & 4.191 \\
\hline 15 t.ha $^{-1}$ & $125.42 \mathrm{c}$ & $12.89 \mathrm{c}$ & $4.40 \mathrm{c}$ & $62.90 \mathrm{~d}$ & $228.82 \mathrm{c}$ & 4.493 \\
\hline 20 t.ha $^{-1}$ & $134.92 \mathrm{~d}$ & $13.96 \mathrm{~d}$ & $4.49 \mathrm{~d}$ & $68.32 \mathrm{e}$ & $231.71 \mathrm{c}$ & 4.880 \\
\hline $\mathrm{BNJ}_{0.05}$ & 6.69 & 0.53 & 0.06 & 3.10 & 7.46 & \\
\hline
\end{tabular}

Keterangan: *) Angka-angka pada kolom sama diikuti oleh sama tidak berbeda nyata menurut uji $\mathrm{BNJ}_{0.05} ; 1$, bobot tongkol kering panen per tanaman $(\mathrm{g}) ; 2$, panjang tongkol $(\mathrm{cm}) ; 3$, diameter tongkol $(\mathrm{cm}) ; 4$, bobot biji kering pipil per tanaman $(\mathrm{g})$ dan 5, bobot 1.000 butir biji (g).

Tabel 8. Nilai koefisien korelasi antar karakter dengan daya hasil

\begin{tabular}{clc}
\hline No. & \multicolumn{1}{c}{ Karakter yang diamati } & $\begin{array}{c}\text { Nilai koefisien korelasi dengan } \\
\text { daya hasil }\end{array}$ \\
\hline 1 & Tinggi tanaman umur 14 hari & $0.034 \mathrm{~ns}$ \\
2 & Tinggi tanaman umur 28 hari & $0.151 \mathrm{~ns}$ \\
3 & Tinggi tanaman umur 42 hari & $-0.045 \mathrm{~ns}$ \\
4 & Jumlah daun per tanaman umur 14 hari & $0.506 \mathrm{~s}$ \\
5 & Jumlah daun per tanaman umur 28 hari & $0.604 \mathrm{~s}$ \\
6 & Jumlah daun per tanaman umur 42 hari & $0.387 \mathrm{~s}$ \\
7 & Umur keluar malai & $0.480 \mathrm{~s}$ \\
8 & Umur keluar rambut tongkol & $0.445 \mathrm{~s}$ \\
9 & ASI & $-0.124 \mathrm{~ns}$ \\
10 & Umur panen & $0.484 \mathrm{~s}$ \\
11 & Bobot tongkol kering panen per tanaman & $0.942 \mathrm{~s}$ \\
12 & Panjang tongkol & $0.750 \mathrm{~s}$ \\
13 & Diameter tongkol & $0.707 \mathrm{~s}$ \\
14 & Bobot 1.000 butir biji & $0.703 \mathrm{~s}$ \\
\hline
\end{tabular}

Keterangan: s, berbeda nyata pada taraf 5 persen dan ns, berbeda tidak nyata.

Keeratan hubungan antar karakter dengan daya hasil, dapat dilihat dari nilai koefisien korelasinya, seperti disajikan pada Tabel 8. Pata Tabel 8 terlihat, bahwa bobot tongkol kering panen memiliki hubungan dengan daya hasil paling erat, yakni 0.942; kemudian diikuti oleh panjang tongkol, diameter tongkol dan bobot 1.000 butir biji masing-masing $0.750,0.707$ dan 0.703. Umur keluar malai, umur keluar rambut tongkol dan umur panen serta jumlah daun umur 14, 28 dan 42 hari juga memiliki koefisien korelasi yang nyata. Tinggi tanaman umur 14, 28 dan 42 hari tidak memiliki keeratan hubungan dengan daya hasil.

Varietas Lamuru pada pemberian takaran pupuk kandang sapi 20 t.ha $^{-1}$, memiliki daya hasil lebih tinggi dibanding kombinasi perlakuan lainnya pada kondisi cekaman kekeringan. 
Hal ini dapat terjadi karena pada takaran 20 t.ha $^{-1}$ menyebabkan kemampuan tanah untuk memegang air lebih tinggi dibanding takaran yang lebih sedikit dan varietas Lamuru lebih tahan terhadap cekaman kekeringan. Hal ini sesuai dengan hasil penelitian Tota Suhendrata (2012), bahwa apabila air terbatas, maka varietas Lamuru lebih berpeluang untuk dikembangkan karena toleran kekeringan. Hal ini terlihat pula pada Gambar 1, bahwa pada takaran pupuk kandang sapi antara 15-20 t.ha ${ }^{-1}$, peningkatan daya hasil varietas Lamuru jauh lebih tinggi dibanding varietas lain.

Daya hasil varietas komposit Lamuru dan Sukmaraga yang diuji pada kondisi cekaman kekeringan di lahan kering, lebih tinggi dibanding populasi P4IS, Gumarang dan NK212. Kedua varietas tersebut merupakan komposit; tersusun atas berbagai genotipe, sehingga lebih toleran terhadap kondisi sub optimal seperti cekaman kekeringan (Mejaya et al., 2010). Kedua varietas tersebut memiliki toleransi lebih tinggi dibanding varietas lain pada saat terjadi cekaman kekeringan. Dalam penelitian ini cekaman kekeringan terjadi pada fase vegetatif, pembungaan dan pengisian biji karena tidak terjadi hujan dengan curah hujan yang cukup pada fase tersebut. Menurut Mahanna et al. (2012), bahwa periode kritis air untuk tanaman jagung mulai dari fase vegetatif hingga pengisian biji; namun dampaknya terhadap penurunan produksi berbeda dan paling tinggi pada saat keluarnya rambut tongkol/memencarnya polen, tergantung pada varietas yang diuji. Selain itu, Sukmaraga memiliki potensi hasil lebih tinggi dibanding komposit lain (P4IS dan Gumarang). Lamuru memiliki potensi lebih rendah dibanding Gumarang karena dalam pembentukannya ditujukan untuk lahan kering (Balitjas, 2013). Komponen hasil kedua varietas tersebut meliputi bobot tongkol kering panen, panjang tongkol, diameter tongkol dan bobot 1.000 butir biji, lebih tinggi dibanding varietas lain yang diuji (Tabel 3). Hal ini menunjukkan, bahwa pada kondisi cekaman kekeringan kerusakan jaringan organ generatif lebih sedikit (Chen et al., 2012). Komponen hasil sangat mendukung diperoleh daya hasil lebih tinggi terlihat dari nilai koefisien korelasinya tinggi, yakni lebih dari 0.700 (Tabel 8).

Daya hasil seluruh varietas yang diuji, menunjukkan daya hasil yang lebih rendah dibanding potensi hasil masing-masing varietas. Potensi hasil varietas komposit yang diuji berkisar 7.6-8.5 t.ha ${ }^{-1}$ (Balitjas, 2013) dan hibrida NK212, lebih dari 13 t.ha ${ }^{-1}$ (Syngenta, 2015); populasi P4IS, 5.5 t.ha $^{-1}$. Daya hasil yang diperoleh, berturut-turut untuk P4IS, Gumarang, Lamuru, Sukmaraga dan NK212, yaitu 3.272, 3.749, 4.191, 4.493, dan 4.880 t.ha ${ }^{1}$. Dampak cekaman kekeringan terjadi pada seluruh varietas; namun karena tingkat toleransi antar varietas berbeda, maka daya hasilnya berbeda pula. Cekaman yang terjadi pada fase vegetatif lanjut, menyebabkan tanaman lebih pendek, terlihat dari tinggi tanaman umur 42 hari dan jumlah daun berkurang (Tabel 2). Cekaman kekeringan pada fase pembungaan sangat berpengaruh pula terhadap daya hasil. Hal ini dapat terjadi karena rambut tongkol keluar terlambat dan waktu pecahnya kotaksari lebih pendek (Wijayanto et al. (2014). Pada kondisi normal, periode penyerbukan-pembuahan selama 6 hari; sedangkan kondisi stress kekeringan, periode penyerbukan lebih pendek, yakni 1-2 hari. Kedua hal ini menyebabkan sebagian tongkol tidak berisi dan akhirnya hasil berkurang (Hall dan Twidwell, 2002). Umur panen yang lebih cepat juga dapat menyebabkan rendahnya daya hasil.

Umur panen antar varietas yang diuji, berbeda-beda; dengan populasi P4IS paling genjah, kemudian diikuti oleh varietas Gumarang, Lamuru, Sukmaraga dan hibrida NK212. Urutan mulai dari umur paling genjah hingga paling dalam tersebut. Hal ini sesuai dengan 
deskripsi, yaitu umur panen P4IS, 78 hari (Sudika et al. (2014), Gumarang, 82 hari, Lamuru 85 hari, Sukmaraga, 105 hari (Balitjas, 2013) dan NK212, 105-110 hari (Syngenta, 2015); namunlebih cepat dibandingkan dengan deskripsi varietas sebagai akibat adanya cekaman kekeringan di lahan kering. Pembungaan yang terlambat dan panen lebih awal; menunjukkan periode pengisian biji lebih pendek, sehingga hasil seluruh varietas yang diuji jauh lebih rendah dibanding potensi hasil.

Perbedaan takaran pupuk kandang sapi yang diberikan pada tanaman jagung menyebabkan daya hasil yang berbeda. Takaran pupuk kandang 20 t.ha ${ }^{-1}$ memberikan hasil lebih tinggi dibandingkan takaran lebih rendah. Antar takaran pupuk kandang sapi, menyebabkan umur panen berbeda. Takaran $20 \mathrm{t} . h a^{-1}$ menyebabkan panen lebih lambat dibanding takaran yang lebih rendah.Umur panen umumnya ditentukan oleh umur keluar rambut tongkol. Semakin lambat umur keluar rambut tongkol, maka panennya semakin lambat pula. Pada Tabel 6, terlihat antar takaran tidak menyebabkan perbedaan umur keluar rambut tongkol. Hal ini menunjukkan bahwa fase mengisian biji pada takaran 20 t.ha $^{-1}$ lebih lama dibanding takaran lebih rendah.Pemberian pupuk kandang dengan takaran tertinggi tersebut, kemungkinan menyebabkan kemampuan tanah untuk memegang air lebih lama, sehingga kekurangan air pada saat pengisian biji lebih sedikit. Hal ini didukung oleh pendapat Adijaya dan Yasa (2014), bahwa pupuk kandang sapi dapat memperbaiki sifat fisik tanah antara lain meningkatkan kadar air tanah. Adanya kemampuan tanah untuk memegang air lebih banyak dan fase pengisian biji lebih lama, maka daya hasil akan lebih tinggi.

\section{KESIMPULAN}

Kesimpulan yang dapat dikemukakan sebagai hasil penelitian dan pembahasan, sebagai berikut:

1. Daya hasil tanaman jagung tertinggi, diperoleh pada varietas Lamuru dengan takaran pupuk kandang sapi 20 t.ha ${ }^{-1}$, yakni 85.94 gram per tanaman (6. 139 t.ha $\left.{ }^{-1}\right)$.

2. Daya hasil varietas Lamuru sama dengan Sukmaraga dan lebih tinggi dibanding dengan P4IS, Gumarang, dan hibrida NK212.

3. Takaran pupuk kandang sapi sebesar 20 t.ha ${ }^{-1}$ memberikan daya hasil tanaman jagung tertinggi.

4. Agar memperoleh kepastian hasil untuk penanaman jagung di lahan kering; yang sering mengalami cekaman kekeringan, maka disarankan untuk menggunakan varietas Lamuru dan diberi pupuk kandang sapi sebanyak 20 t.ha ${ }^{-1}$.

\section{Ucapan Terima Kasih}

Tim mengucapkan terima kasih kepada Kementerian Riset, Teknologi dan Pendidikan Tinggi atas dana yang telah diberikan, sehingga penelitian ini dapat berlangsung sesuai diharapkan. Ucapan terima kasih juga ditujukan kepada Ketua dan seluruh staf LPPM Universitas Mataram, atas segala saran, bantuan dan fasilitas, sehingga seluruh kegiatan dapat terlaksana. 


\section{DAFTAR PUSTAKA}

Adijaya dan R. Yasa.2014.Pengaruh Pupuk Organik terhadap Sifat Tanah, Pertumbuhan dan Hasil Jagung.Prosiding Seminar Nasional "Inovasi Teknologi Pertanian Spesifik Lokasi”.Banjarbaru. 299-310.

Anonymous. 2012. Breeding for Drought Stress Tolerance. https://en.wikipedia. org/wiki/Breeding_for_drought_stress_tolerance (Diakses, 9 Agustus 2015).

Atmojo, S.W. 2003. Peranan Bahan Organik terhadap Kesuburan Tanah dan Upaya

Pengelolaannya.Pidato Pengukuhan Guru Besar Ilmu Kesuburan Tanah.Universitas Sebelas Maret, Surakarta.

Bara, A. dan A. Chozin. 2010. Pengaruh Dosis Pupuk Kandang dan Frekuensi Pemberian Pupuk Urea terhadap Pertumbuhan dan Produksi Jagung (Zea mays L.) di Lahan Kering.Makalah Seminar Departemen Agronomi dan Hortikultura Fakultas Pertanian Institut Pertanian Bogor.

Balitjas. 2013. Deskripsi Varietas Unggul Jagung Edisi 2013. Pusat Penelitian dan Pengembangan Tanaman Pangan, Maros.

Chen, J., W. Xu, J. Velten, Z. Xin and J. Stout. 2012. Characterization of Maize Inbred Lines for Drouht and Heat Tolerance. J. of Soil and Water Cons. 67 (5):354-364.

Edmeades, G.O. 2013. Progress in Achieving and Delivering Drought Tolerance in Maize An -Update. The International Service for TheAcquisition of Agri-Biotech Aprications (ISAAA). $44 \mathrm{p}$.

Efendi, R. dan M. Azrai. 2010. Tanggap Genotipe Jagung terhadap Cekaman Kekeringan: Peranan Akar. Jurnal Penelitian Pertanian Tanaman Pangan 29(1):1-10.

Hall, R. C., and E.K Twidwell, 2002. Effects of Drought Stress on Corn Production.Collage of Agriculture \& Biological Science/South Dakota State University/USDA.http://agbiopubs.sdstate.edu/articles/ExEx8033.pdf. (Diakses 27 Desember 2013).

Hasanuzzaman, M., K. Nahar, S.S. Gill, R. Gill dan M. Fujita. 2014.Drought Stress Responses in Plants, Oxidative Stress, and Antioxidant Defense. P. 209 - 254. In Climate Change and Plant Abiotic Stress (First Edition). Wiley-VCH Verlag GmbH \& Co.KGaA.

Indriani, F.C. dan Mejaya. 2012. Toleransi Genotipe Jagung Biji Putih terhadap Cekaman Kekeringan.Hal. 411 - 420. Prosiding Seminar Nasional Pusat Penelitian dan Pengembangan Tanaman Pangan, Badan Penelitian dan Pengembangan Pertanian.

Jaya, D., Sudirman, and Jayaputra. 2015. Growth Stand and Yield Performances of Some Modern Superior Maize Hybrid Varieties Grown Under Different Population Densities on a Dryland. Presented at International Conference on Mathematics and Sciences Education, Lombok Indonesia.5 p.

Mahanna, B., B. Curran and B. Seglar, DVM. 2012. Management of Drouht-Stressed Corn Silage. Pioneer Nutritional Sciences and Sales Support. (Diakses 27 Desember 2013)

Mejaya, M. J., Azrai dan R. N. Iriany. 2010. Pembentukan Varietas Unggul Jagung Bersari Bebas. Hal. 55-73. Dalam Jagung: Teknik Produksi dan Pengembangan. Litbang Deptan.

Sudika, Idris dan Soemeinaboedhy. 2014. Pengembangan Varietas Unggul Jagung untuk Lahan Kering Dengan Umur Genjah ( $<80$ hari), Hasil Tinggi ( $>6.00$ t/ha) Dan Berat 
Brangkasan Segar Tinggi (> 300 g/tanaman). (Laporan Hasil Penelitian Insinas Ristek

Tahun II). Universitas Mataram, Mataram.

Syngenta. 2015. Awali dengan Benar (Buku Panduan). PT Syngenta, Jakarta.

Tajidan.2014. Manajemen Rantai Pasok dan Integrasi Proses Bisnis dalam Upaya Peningkatan Kesejahteraan Petani Jagung di Provinsi Nusa Tenggara Barat (Disertasi).

Program Pascasarjana Universitas Brawijaya, Malang.

Tota Suhendrata. 2012. Introduksi Beberapa Jagung Komposit Varietas Unggul pada Lahan

Kering dalam Upaya Menunjang Kedaulatan Pangan di Kabupaten Sregen. Makalah dalam Seminar Nasional Fakultas Pertanian Universitas Trunojoyo, Madura.

Wijayanto, T., C. Ginting, V. Boer dan Wa Ode Afu.2014. Ketahanan Sumber Daya Genetik Jagung Sulawesi TenggaraTerhadap Cekaman Kekeringanpada Berbagai Fase Vegetatif. Agroteknos. 4(2): 101-106

Xoconostle-Cazares, B., F.A. Ramirez-Ortega, L. Flores-Elones and R. Ruiz-Medrano. 2012.

Drought Tolerance in Crop Plants. American J. of Plant Physiol: 1-16. 